\title{
Experimental Study on Super-heated Steam Drying of Lignite
}

\author{
Yongchun $\mathrm{Shi}^{1,2, a}$, Jie $\mathrm{Li}^{2}{ }^{\text {b* }}$, Xuanyou $\mathrm{Li}^{2}$, Jing $\mathrm{Wu}^{1,2}$, Maogang $\mathrm{Wu}^{2}$, \\ Sheng $\mathrm{Li}^{2}$, Hongyao Wang ${ }^{2}$, Gaiju Zhao ${ }^{2}$ and Fengjiao Yin ${ }^{2}$ \\ ${ }^{1}$ School of Energy and Power Engineering, Shandong University, Jinan, China \\ ${ }^{2}$ Industrial Energy Conservation Research Center of Shandong Academy of Sciences, Jinan, China \\ ashiyc-tl@hotmail.com, bjeff_lee@foxmail.com
}

Keywords: lignite; super-heated steam drying; drying kinetics; hot air drying; drying curve; drying rate.

\begin{abstract}
This paper applies super-heated steam drying technology to improve the quality of lignite. A unique experimental system was built up. In order to obtain the optimum operation conditions, the drying kinetics was measured. The temperature range of super-heated steam was from 120 to $200^{\circ} \mathrm{C}$. The results showed that the drying process of super-heated steam drying of lignite can be well depicted by two stages, as a constant drying rate stage followed by a falling drying rate stage. The comparison of drying process to the hot air drying showed the superior advantages of super-heated steam drying on safety, drying capacity and energy conservation. Analysis shows the huge application potential of lignite in power plants by means of the super-heated steam drying.
\end{abstract}

\section{Introduction}

Undoubtedly, coal remains the most important primary energy source in China. Coal can be classified as bituminous coal, anthracite and lignite according to the rank of coalification. Nowadays, high rank coals including the bituminous coal and anthracite in China have been made full use. As a result, their development space is limited. To satisfy the requirement of energy, people begin to make comprehensive exploitation of lignite, due to the relatively abundant Lignite resources in China. The proved reserves of lignite are 130.3 billion tons, about $13 \%$ in the total [1]. However, the average field moisture contents of lignite are high, usually rang from $30 \%$ to $50 \%$. If raw lignite is burned directly, serials problems must result in, such as insufficient combustion, additional exhaust gas discharge and additional energy consumption to evaporate the moisture. So, finding the proper drying and upgrading methods for lignite gain more and more interests in present.

Among a large number of drying technologies, super-heated steam drying method shows the superior advantages on safety, drying capacity and energy conservation for dewater lignite. Because it is possible to recover all of the latent heat supplied in the super-heated steam drying from the exhaust by condensing the exhaust stream, reduced energy consumption is a clear advantage of super-heated steam drying. The degree of moisture removal of lignite as a function of both temperature and superheat was studied by Bongers et al. [2]. They also studied the shrinkage and physical properties of lignite during high pressure steam drying [3]. Chen et al. [4, 5] developed mathematical model to simulate the drying of lignite in super-heated steam. Although there is a widespread concern on the super-heated steam drying technology, the research on the lignite drying using super-heated steam are few.

In resent years, the Industrial Energy Conservation Research Center of Shandong Academy of Sciences focus itself on the research of drying and upgrading for lignite. A number of unique drying systems were developed, such as fluidized-bed with inner-heater super-heated steam drying system and rotary superheated steam drying system. This paper aims finding the drying kinetics features of lignite to provide the necessary data for design of lignite super-heated steam drying system. 


\section{Experiments}

In order to investigate the drying kinetics of lignite, a special experimental apparatus was designed and built, showing in Fig. 1. Pure water in a tank (6) was dosed by a pump (7) to an electric heater (9) to generate steam, further heated to a desired temperature by another electric heater (12). In order to take the consideration of air influences to the drying features, an air stream was introduced to the experimental system. The air flow was heated to a desired temperature by the third electric heater (4), then mixes with the steam in a mixing chamber (11). The lignite sample was put in the testing chamber (14) by a sample tray (15), which connects to an electronic balance (13, METTLER TOLEDO, PL3002, 0.01g) to measure the mass changes during drying. The flow rate of the steam was controlled by the dosing pump (7), measured by a flow meter (8). The flow rate of the air was controlled by an adjusting valve (2) assembled downstream the air compressor (1). A serial of thermocouples was employed to measure temperatures of the steam and air.

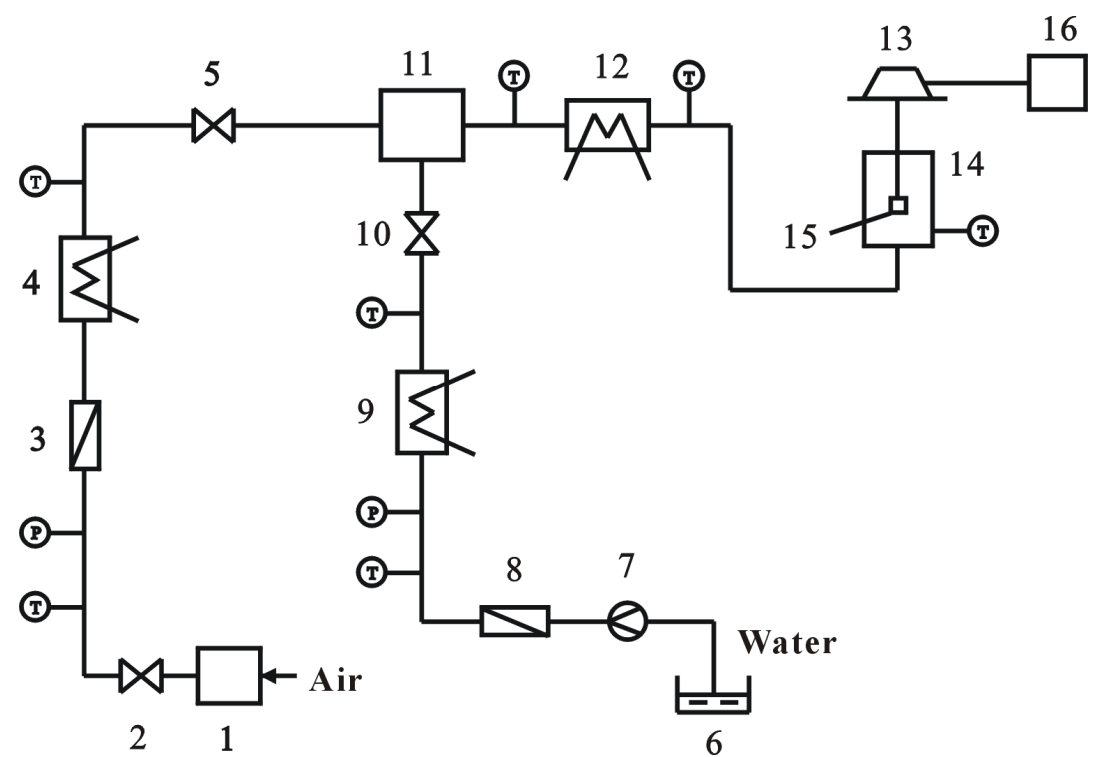

Fig. 1. Schematic diagram of the super-heated steam processing system, 1-air compressor, 2-value, 3-flow meter, 4-electric heater, 5-valve, 6-tank, 7-dosing pump, 8-flow meter, 9- electric heater, 10-value, 11-gas mixing chamber, 12-elctric heater, 13- electric balance, 14- testing chamber, 15- sample tray, 16-computer, T- thermocouple, P-pressure gauge

This testing system can perform the following functions: (1) drying lignite by super-heated steam flow; (2) drying lignite by hot air flow; (3) drying lignite by super-heated steam flow mixed with hot air.

\section{Results and discussion}

In this paper, the drying gases in the drying installation chamber were at atmospheric pressure $(0.1 \mathrm{MPa})$ with a velocity of $0.5 \mathrm{~m} / \mathrm{s}$. The testing temperature was in the range from $120^{\circ} \mathrm{C}$ to $400^{\circ} \mathrm{C}$.

Lignite sample used in the experiments was transported from Coal Mine Pingzhuang, China. Lignite was crushed to a diameter range of $0.1 \sim 2 \mathrm{~mm}$ by a coal pulverizer. The moisture content of the lignite sample was $38.68 \%$ dry mass basis $(\mathrm{db})$. The moisture content of the lignite sample was determined by an infrared moisture analyzer. Each lignite sample prepared for the drying experiment was weighed approximately $5.0 \mathrm{~g}$. The thickness of each lignite sample in the sample tray is approximately $15 \mathrm{~mm}$.

Super-heated steam drying. Fig. 2 shows drying curves for lignite in super-heated steam at various steam temperatures. It was found that, at the beginning the measured initial moisture content was significant higher than the raw material $(38.68 \%, \mathrm{db})$ when the temperature was in the range of $120-200^{\circ} \mathrm{C}$. An amount of moisture was gained on the lignite sample surface from the steam condensation while the sample was brought up from the room temperature to $100^{\circ} \mathrm{C}$. It also can be 
seen in Fig. 2 that the lignite sample gained more moisture in low temperature steam than in high temperature steam. When the steam temperature reaches a certain value (about $350^{\circ} \mathrm{C}$ in our test), the measured initial moisture content in the test was nearly equal to the raw material. One of the possibilities is that, when the steam temperature is high enough, high heat transfer speed results in a high lignite particles' surface temperature in very short time. This phenomenon also demonstrates the important role of superheat degree in the steam condensation. The influence of moisture condensation on heat and mass transfer is to be carried out in our further steps of investigation.

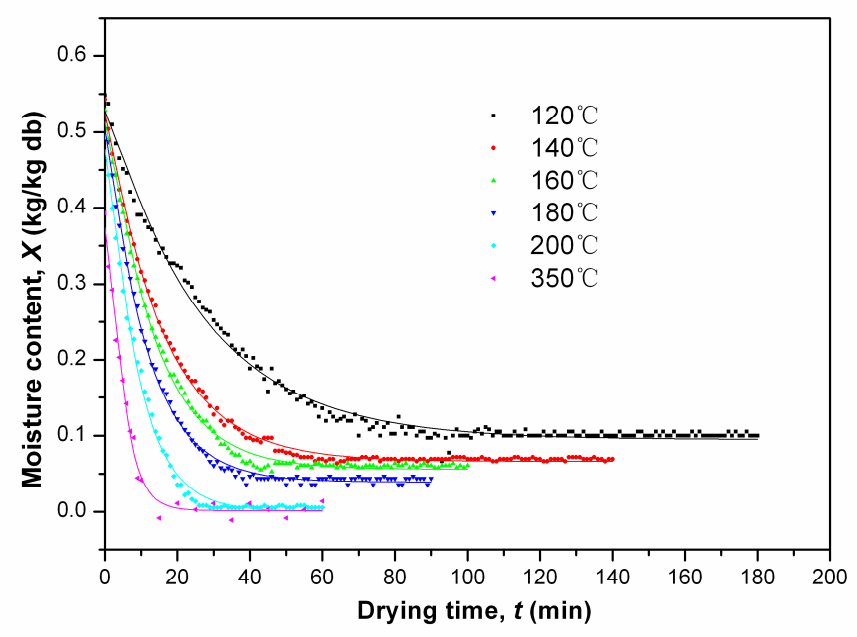

Fig. 2. Drying curves for lignite in superheated steam at various steam temperatures

As Fig. 2 shows, all the drying curves can be divided by the two drying periods: constant drying rate and falling drying rate. An Empirical model $[6,7]$ was applied in this paper to describe the drying curves, as shown in Eq. 1 and Eq. 2:

$$
\begin{array}{r}
X=X_{0}-\left(X_{0}-X_{c r}\right) \times t / t_{c r} \quad \mathrm{X}>\mathrm{X}_{\mathrm{cr}} \\
X=X_{e q}+\left(X_{c r}-X_{e q}\right) \times \exp \left(-\frac{X_{0}-X_{c r}}{t_{c r}} \times \frac{t-t_{c r}}{X_{c r}-X_{e q}}\right) \quad \mathrm{X}<\mathrm{X}_{\mathrm{cr}}
\end{array}
$$

Where $X$ is the moisture content $(\mathrm{kg} / \mathrm{kg} \mathrm{db}) ; X_{0}$ is the initial moisture content $(\mathrm{kg} / \mathrm{kg} \mathrm{db}) ; X_{\text {cr }}$ is the critical moisture content $(\mathrm{kg} / \mathrm{kg} \mathrm{db}) ; X_{\mathrm{eq}}$ is the equilibrium moisture content $(\mathrm{kg} / \mathrm{kg} \mathrm{db}) ; t$ is the drying time ( $\mathrm{min}) ; t_{\mathrm{cr}}$ is the drying time when the critical moisture content reached (min).

It was found that the above equations can well match the experimental data with high $R^{2}$ values.

Fig. 3 shows the corresponding drying rate versus moisture content. It was found that, in the falling drying rate period, all the curves can be described by a linear line. The drying rate in constant period increased as the steam temperature increased.

Fig. 2 and Fig. 3 show that the superheat degree of steam affects the final moisture content significantly. In the experiments, the final moisture content decreased as the steam temperature increased. It was also observed that the critical moisture content decreased as the steam temperature increased. This dedicates that during the drying process, the shrinkage of lignite particles is relative weak. Further investigation on shrinkage in drying process of lignite is also to be performed in our next steps. 


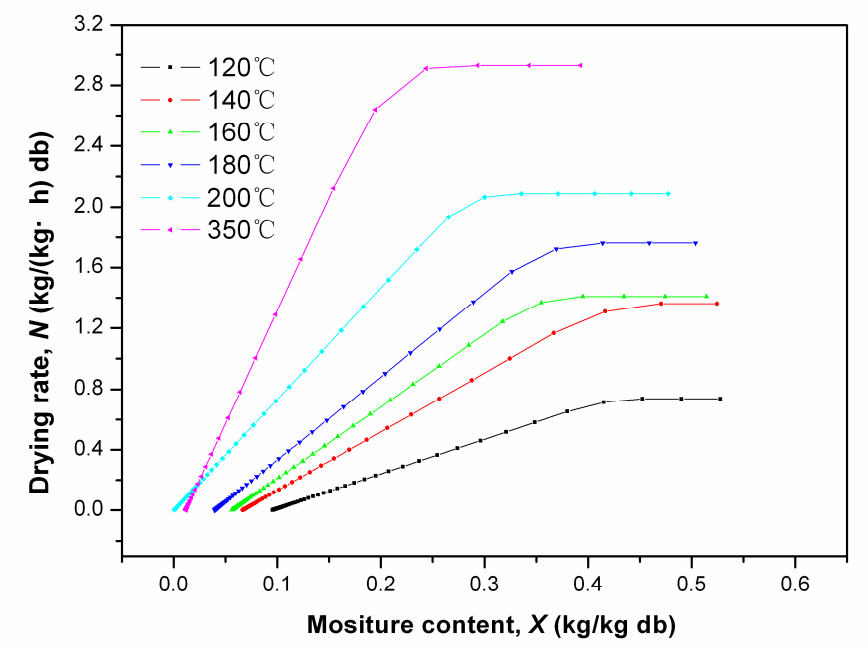

Fig. 3. Drying rate curves for lignite in superheated steam at various steam temperatures

Hot air drying. In order to compare the drying feature, serial experiments of hot air drying lignite were performed too. The humidity of air was approximately $50 \%$ in the environmental temperature. Fig. 4 shows the profiles of moisture content versus drying time, correspond the air temperatures of $120^{\circ} \mathrm{C}, 140^{\circ} \mathrm{C}$ and $160^{\circ} \mathrm{C}$. Similar to the super-heated steam drying, the hot air drying curves can also be well described by the two stages, i.e., a constant rate stage followed by a falling rate stage.

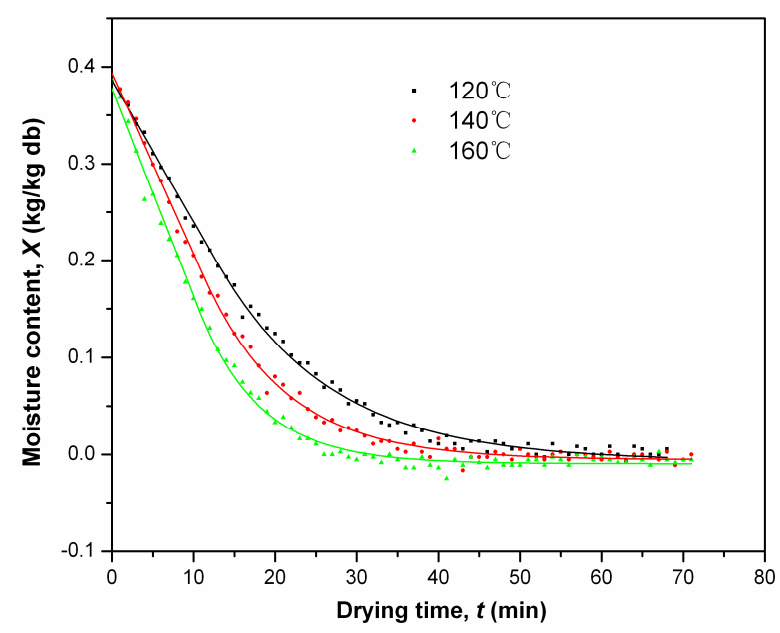

Fig. 4. Drying curves for lignite in hot air at various air temperatures $\left(120^{\circ} \mathrm{C}, 140^{\circ} \mathrm{C}\right.$ and $\left.160^{\circ} \mathrm{C}\right)$

Fig. 5 shows the lignite weight versus drying time curves for the hot air drying at air temperatures of $180^{\circ} \mathrm{C}$ and $200^{\circ} \mathrm{C}$. Different from the above drying curves, each curve presents an additional turning point. The reason is that, at such high temperatures, the lignite sample not just loses the moisture content but also loses other contents i.e. volatile and fixed carbon. It also means that the combustion most possibly takes place. Conversely, the lignite sample only lost the moisture content even at a very high drying temperature, for instance $350^{\circ} \mathrm{C}$ in our experiments, as seen in Fig. 2. The above results confirmed the high lever safety of drying lignite by super-heated steam. 


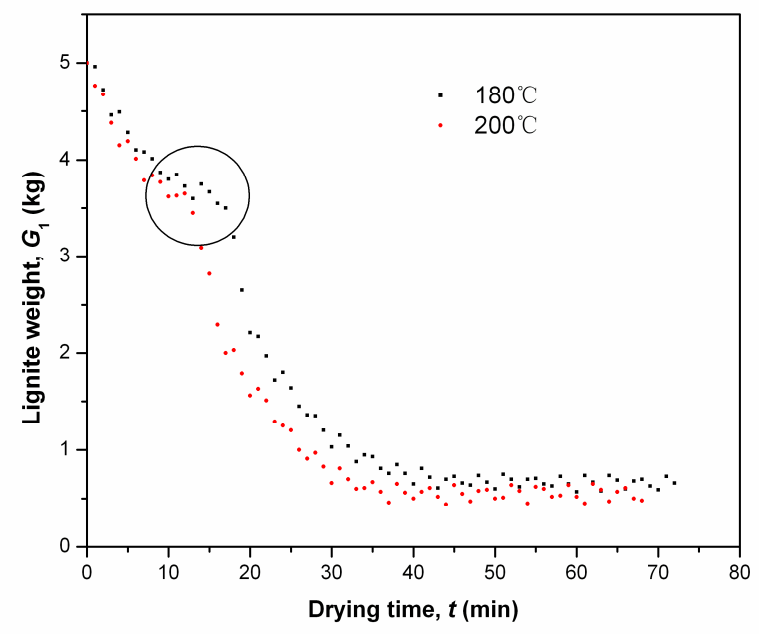

Fig. 5. Lignite weight curves in hot air at air temperatures of $180^{\circ} \mathrm{C}$ and $200^{\circ} \mathrm{C}$

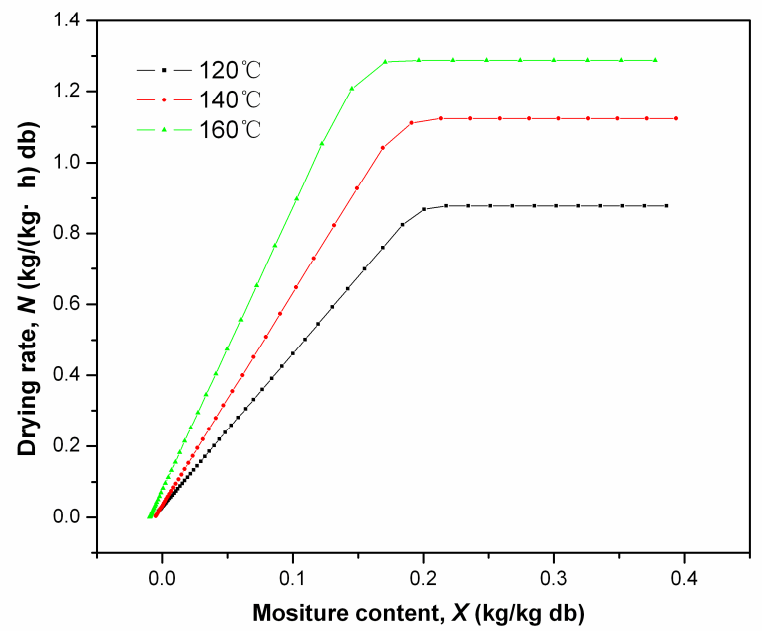

Fig. 6. Drying rate curves for lignite in hot air at various air temperatures $\left(120^{\circ} \mathrm{C}, 140^{\circ} \mathrm{C}\right.$ and $\left.160^{\circ} \mathrm{C}\right)$

The drying rate curves of lignite using hot air drying at different experimental temperatures are shown in Fig. 6. The drying rate in hot air increased as the air temperature increased from 120 to $160^{\circ} \mathrm{C}$ as well as in super-heated steam. However, unlike to the results of super-heated steam drying, the final moisture contents of lignite using hot air drying were nearly 0 when the temperatures were in the range of $120^{\circ} \mathrm{C}$ and $160^{\circ} \mathrm{C}$.

Table 1. Drying rates of lignite for the super-heated steam drying and hot air drying $\mathrm{kg} /(\mathrm{kg} \cdot \mathrm{h})$

\begin{tabular}{lccc}
\hline Temperature & $120^{\circ} \mathrm{C}$ & $140^{\circ} \mathrm{C}$ & $160^{\circ} \mathrm{C}$ \\
\hline Super-heated steam drying & 0.7384 & 1.3611 & 1.4090 \\
Hot air drying & 0.8776 & 1.1229 & 1.2875 \\
\hline
\end{tabular}


Table 1 lists the lignite drying rates in constant drying rate period for super-heated steam and hot air. The comparison shows that the drying rate in super-heated steam drying was lower than in hot air at the temperature of $120^{\circ} \mathrm{C}$, but the drying rate in super-heated steam was higher than in hot air when the temperature was $140^{\circ} \mathrm{C}$ or $160^{\circ} \mathrm{C}$. The inversion temperature in our experiments was in the range from 120 to $140^{\circ} \mathrm{C}$.

\section{Conclusions}

(1) The drying curves of lignite can be represented by a constant drying rate period followed by a falling drying rate period for both super-heated steam drying and hot air drying.

(2) The critical moisture content decreased as the steam temperature increased.

(3) If air temperature beyond $180^{\circ} \mathrm{C}$, the lignite can combust during drying. Super-heated steam drying is a safe drying method for lignite.

(4) The inversion temperature in our experiments is in the range from 120 to $140^{\circ} \mathrm{C}$.

\section{Acknowledgements}

This work was financially supported by Doctoral Fund of Shandong Academy of Science.

\section{References}

[1] H. Dai, and K. Xie: Utilization technology of lignite (China Coal Industry Publishing House, Beijing 1999) (In Chinese).

[2] G. D. Bongers, W. R. Jackson and F. Woskoboenko: Fuel Processing Technology, Vol. 57 (1998), p. 41.

[3] G. D. Bongers, W. R. Jackson and F. Woskoboenko: Fuel Processing Technology, Vol. 64 (2000), p. 13.

[4] Z. Chen, W.Wu and P. K. Agarwal: Fuel, Vol. 79 (2000), p. 961.

[5] Z. Chen, P. K. Agarwa and J. B. Agnew: Fuel, Vol. 80 (2001), p. 209.

[6] W. E. Ranz and W. R. Marshall: Chemical Engineering Progress, Vol. 48 (1952), p. 141.

[7] X. Li and I. Zbicinski: The proceedings of the 5th Asia-Pacific drying conference, p. 337. 
Renewable and Sustainable Energy

10.4028/www.scientific.net/AMR.347-353

Experimental Study on Super-Heated Steam Drying of Lignite

10.4028/www.scientific.net/AMR.347-353.3077 